\title{
SEROLOGICAL PREVALENCE OF OVINE AND CAPRINE BRUCELLOSIS IN BANGLADESH
}

\author{
N. M. Shafy ${ }^{1}$, B. S. Ahmed ${ }^{1}$, R. R. Sarker ${ }^{1}$, K. S. A. Millat ${ }^{1}$, M. T. Hasan ${ }^{2}$, P. K. Bhattacharjee ${ }^{1}$, A. \\ Chakrabartty $^{1}$, A. Paul ${ }^{1}$, M. A. S. Sarker ${ }^{1}$, T. Truong ${ }^{3}$, M. S. Rahman ${ }^{1 *}$ \\ ${ }^{1}$ Department of Medicine, Faculty of Veterinary Science, Bangladesh Agricultural University, Mymensingh \\ 2202, Bangladesh; ${ }^{2}$ Military Farm, Chittagong, Bangladesh; ${ }^{3}$ National Centre for Foreign Animal Disease \\ (NCFAD), 1015 Arlington street, Winnipeg, Manitoba, R3E3M4, Canada
}

\begin{abstract}
Brucellosis is considered to be the most widespread zoonosis throughout the world. It has a serious implication on human health as well as on the economic development in a developing country like Bangladesh. The objective of the present study was to determine the seroprevalence and to delineate the risk factors for Brucella seropositivity in small ruminants in Mymensingh district of Bangladesh. In the present study, serum samples were collected from a total of 2456 small ruminants (1710 goat and 746 sheep) from 13 upazilla of Mymensingh district. The data related to age, sex and location were also collected using a questionnaire. Serum samples were screened using Rose Bengal Test (RBT) and Enzyme Linked Immunosorbent Assay (ELISA). Seroprevalence of brucellosis was $9.53 \%$ in goats and $9.92 \%$ in sheep on RBT test. In goat, the highest Brucella antibody was observed in Mymensingh sadar upazilla (13\%) followed by Dhobaura upazilla (12.9\%). On the other hand, highest ovine Brucella antibody observed in Haluaghat upazilla (13.04\%) followed by Mymensingh sadar (12.5\%). The prevalence was more in adults (55.2\% in goats and $57 \%$ in sheep) than young (8.6\% in goat and $8.1 \%$ in sheep) and more in female goats (41.1\%) and sheep (39.2\%) than male goats (14.1\%) and sheep (18\%). ELISA test showed 33.70\% (31 out of 92 RBT positive samples) positive reaction of total RBT positive reactors. The result of this study can be useful to initiate and establish a program for controlling and prevention through test and slaughter, culling of infected animal from flock and vaccination.
\end{abstract}

Key words: Brucellosis, RBT, iELISA, goat, sheep, prevalence, Mymensingh.

\section{INTRODUCTION}

Caprine and ovine brucellosis caused by zoonotic gram-negative, coccobacillae, facultative intracellular bacteria which belong to the genus Brucella, comprising at least 10 species which includes Brucella melitensis one of three biovars (biovars 1, 2 and 3) and B. ovis as well as many other species is an economically important cause of abortion in small ruminants causes significant losses from decreased productivity and lost trade in much of the developing world. The natural reservoirs of the species $B$. melitensis are basically goats and sheep but also cattle and swine. However, B. ovis is primarily afflicting sheep (Lopes et al., 2010; CFSPH, 2009; Olsen and Palmer, 2014). Brucellosis has a considerable impact on human and animal health as well as a socioeconomic impact, and especially in rural areas that largely rely on livestock and in developing countries still considered as the most serious and devastating zoonotic disease (Al-Majali, 2005; Al-Majali et al., 2007; Rahman et al., 2015). In animals, brucellosis causes severe economic losses as result of stormy abortions or reproductive failure, sterility and reduced milk production rates, besides to that, it adds to the burden shouldered by the farmers; the costs of control and management as well as reduces the Foreign Exchange Earnings (FEE) by denying exportation of sheep to international markets (McDermott, 2013; Angara and Ali, 2014). However, the causative agent has a very low infectious dose (10 organisms of $B$. melitensis) are sufficient to cause an infection in man (Lopes et al., 2010).

The goat has played an important role in traditional Bengali society among the Asiatic countries, a tropical agro-based developing country economically and culturally, possesses the third largest repository of goats, with a population of more than 14.8 million heads, 57\% of total livestock in Bangladesh, according to the FAO (WHO, 2006; Banglapedia, 2016). Total sheep population has estimated of 1.9 million. In Bangladesh about 83.9 percent

*Corresponding e-mail address: prithul02@yahoo.co.uk

Copyright () 2016 Bangladesh Society for Veterinary Medicine

All rights reserved 0376/2016 


\section{N.M. Shafy and others}

of total households own livestock among which $0.9 \%$ are goat and sheep (Banglapedia, 2016). Each year 127,000 MT representing 25\% of total red meat in Bangladesh are produced from goat and more than $98 \%$ of goats are owned by the small, marginal and landless farmers in the villages (Bangladesh Economic Review, 2011). Important factors that contribute to the spread of brucellosis in goat and sheep include: farming system and practices, farm sanitation, livestock movement, mixing and trading of animals, and sharing of grazing grounds and watering points (Kabagambe et al., 2001; Kadohira, 1997; Omer, 2000).

A lot of undiagnosed cases of abortion, stillbirth and retained placenta which are thought to be down to brucellosis and these have a significant impact on the development of livestock in Bangladesh (Rahman et al., 2011). Mammary gland may also infected in sheep and goats resulting mastitis, commonly observed feature of caprine brucellosis compared with bovine brucellosis characterized by multinodular firmness with watery, clotted milk (Cutler et al., 2005). Prolonged excretion of organisms in milk may occur in goats but less so in sheep (Poester et al., 2013). Brucella ovis is also an important cause of orchitis and epididymitis in sheep but it is not recognized as a cause of natural infection in goats (Jacques, 1998).

Screening of brucellosis in sheep and goat using the RBT and iELISA are generally used for the detection of Brucella antibody in serum collected from suspected animals. ELISA have been evaluated for many years for their ability to detect serum antibodies to brucellosis in domestic animals. ELISA for the diagnosis of brucellosis has several advantages when compared with other tests. First, it directly identifies a specific antibody. Second, it is more sensitive than other agglutination tests and thus has the potential to detect infected animals. Third, ELISA results provide an epidemiological tool for investigating the infection status of flocks in places where vaccination has never been practiced, like Bangladesh (Rahman, 2005). Indirect ELISA test were used along with RBT for more specific result to avoid false positive result in RBT. These can be used for rapid test for identification of brucellosis infection in small ruminants and introduce preventive measures through initiation of vaccination.

\section{MATERIALS AND METHODS}

\section{Sample collection}

To determine the seroprevalence of caprine and ovine brucellosis in Mymensingh district, a survey plan was designed in both longitudinal and cross-sectional dimension covering all upazilla of Mymensingh district. The research was carried out during the period from January to November 2016. Samples were collected from randomly selected native goat and sheep in Mymensingh Sadar (200, 120), Muktagachha (95, 39), Fulbaria (187, 53), Trishal (210, 62), Valuka (120, 42), Tarakanda (72, 35), Gauripur (112, 84), Nandai (55, 80), Ishwarganj $(28,81)$, Gaffargoa $(123,20)$, Dhobaura $(163,35)$, Fulpur $(150,49)$, Haluaghat $(195,46)$. About $5 \mathrm{ml}$ blood was collected from jugular vein of each of the selected goat and sheep 1710 and 746 respectively in separate sterilized test tubes (a total of 2456 sera samples) and kept in refrigerator overnight. The test tube was further refrigerated at $4-8^{\circ} \mathrm{C}$ overnight. Late, the sera were separated from blood clots and centrifuged at $2500 \mathrm{rpm}$ for $10 \mathrm{~min}$ to obtain clear sera free from blood cells. Finally, sera were transferred into a sterilized Eppendorf tube and stored at $-20^{\circ} \mathrm{C}$ until used. The data related to age, sex and location were also collected on the sampling day. Different serological tests, Rose Bengal Plate Test (RBPT) and indirect Enzyme-Linked Immunosorbent Assay (iELISA), were performed to determine the true prevalence of brucellosis.

\section{Rose Bengal Test (RBT)}

Approximate number of processed test sample (serum), sufficient antigen, positive and negative control sera for a day's testing were removed from refrigeration and kept for adjusting at room temperature (approx. $22^{\circ} \mathrm{C}$ ). $30 \mu \mathrm{l}$ of each serum to be tested was placed on a fine plastic plate circled approximately $1.5 \mathrm{~cm}$ in diameter. Then the vial of antigens was shacked gently and $30 \mu \mathrm{l}$ of antigen put beside each of the sera. The antigen and serum was mixed on the plate with a stirrer and spread over the area enclosed by the circle. Then the plate was placed on a mechanical rotator at $90-100 \mathrm{rpm}$ for 3-5 minutes and the reading was taken immediately. Any agglutination or precipitation was considered as positive, whereas no reaction indicated the absence of Brucella antigen in the sera (Figure 4). 


\section{Indirect Enzyme-Linked Immunosorbent Assay (iELISA)}

RBT positive sera was screened with indirect Enzyme-Linked Immunosorbent Assay (iELISA) according the protocol and suppliance provided by the ELISA kit (Svanova Biotech AB, Sweden) as per manufacturer instruction and reading was estimated by automated ELISA reader (Figure 5).

\section{Data analysis}

The data was recorded on excel and were analysed by using SPSS software version 20 (SPSS, Inc., Chicago, IL, USA).

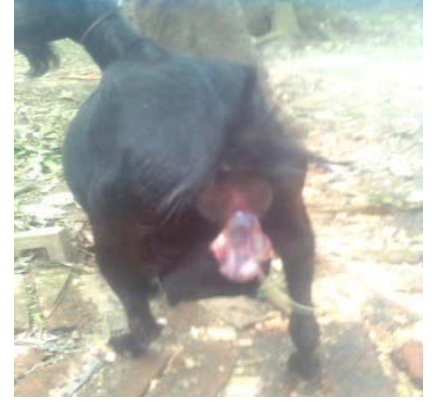

Figure1. Retention of placenta in a goat

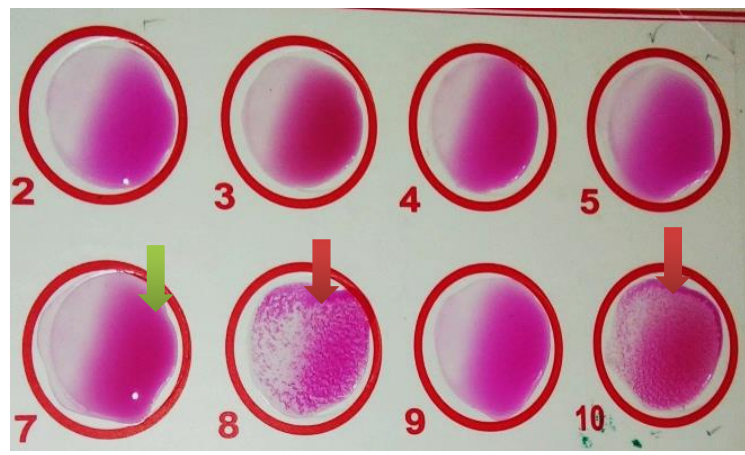

Figure 4. Rose Bangal Test (RBT). Arrows are indicating the positive cases.

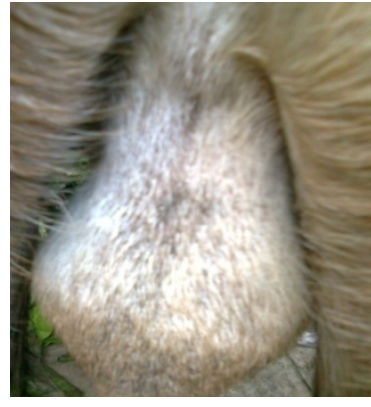

Figure 2. Orchitis in buck

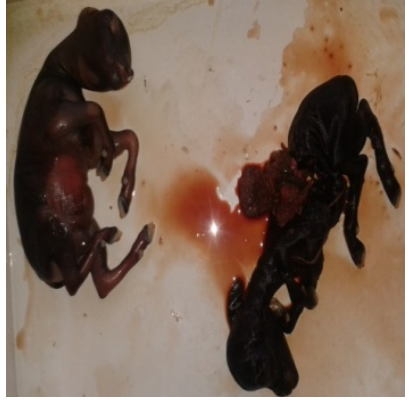

Figure 3. Aborted fetus in a goats

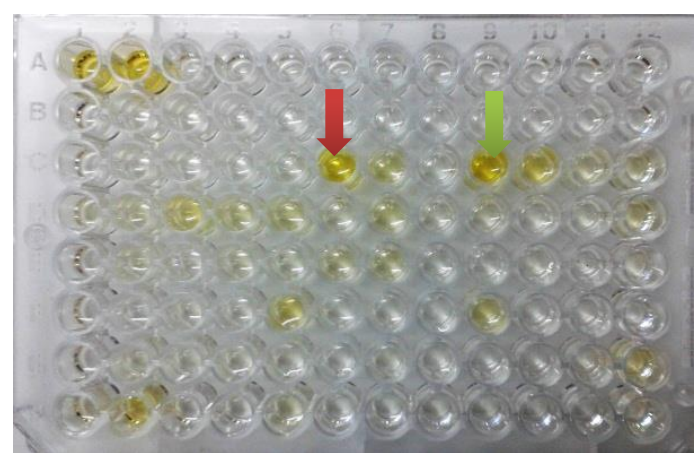

Figure 5. iELISA test result of positive (indicating arrows) RBT serum

\section{RESULTS AND DISCUSSION}

The positive reactor by Rose Bangal Test (RBT) in goat and sheep were 9.53\% (163/1710) and 9.92\% (74/746) respectively. Upazilla wise prevalence ware estimated of goat and sheep (Table 1). The highest caprine Brucella antibody was observed in Mymensingh sadar upazilla (13\%) followed by the upazilla Dhobaura (12.9\%) and highest ovine Brucella antibody observed in upazilla Haluaghat (13.04\%) followed by Mymensingh sadar (12.5\%). In relation to age and sex, adult goats (55.2\%), sheep (57\%) were more positive than young (8.6\%) \& (8.1\%) respectively and female goats (41.1\%), sheep (39.2\%) were more susceptible than male goats (14.1\%) \& sheep (18\%). ELISA test showed 33.70\% of RBT reactors had shown positive reaction (Table 2). 


\section{N.M. Shafy and others}

Table 1. Upazila wise distribution of prevalence of sheep and goat brucellosis (RBT)

\begin{tabular}{|c|c|c|c|c|c|c|c|c|}
\hline \multirow[b]{2}{*}{ Name of Upazilla } & \multicolumn{4}{|c|}{ Goat } & \multicolumn{4}{|c|}{ Sheep } \\
\hline & Negative & Positive & $\begin{array}{c}\text { Total no } \\
\text { of test }\end{array}$ & $\begin{array}{c}\text { Prevalence } \\
(\%)\end{array}$ & Negative & Positive & $\begin{array}{c}\text { Total no } \\
\text { of test }\end{array}$ & $\begin{array}{c}\text { Prevalence } \\
\text { (\%) }\end{array}$ \\
\hline Mymensingh Sadar & 174 & 26 & 200 & 13 & 105 & 15 & 120 & 12.5 \\
\hline Muktagachha & 87 & 8 & 95 & 8.4 & 35 & 4 & 39 & 10.2 \\
\hline Fulbaria & 175 & 12 & 187 & 6.4 & 48 & 5 & 53 & 9.4 \\
\hline Trishal & 186 & 24 & 210 & 11.4 & 55 & 7 & 62 & 11.3 \\
\hline Valuka & 107 & 13 & 120 & 10.8 & 38 & 4 & 42 & 9.5 \\
\hline Tarakanda & 70 & 2 & 72 & 2.7 & 35 & 0 & 35 & 0 \\
\hline Gauripur & 103 & 9 & 112 & 8.0 & 75 & 9 & 84 & 10.7 \\
\hline Nandail & 54 & 1 & 55 & 1.8 & 72 & 8 & 80 & 10 \\
\hline Ishwarganj & 28 & 0 & 28 & 0 & 74 & 7 & 81 & 8.6 \\
\hline Gaffargoan & 114 & 9 & 123 & 7.3 & 20 & 0 & 20 & 0 \\
\hline Dhobaura & 142 & 21 & 163 & 12.9 & 31 & 4 & 35 & 11.4 \\
\hline Fulpur & 136 & 14 & 150 & 9.3 & 44 & 5 & 49 & 10.2 \\
\hline Haluaghat & 171 & 24 & 195 & 12.3 & 40 & 6 & 46 & 13.04 \\
\hline Grand Total & 1547 & 163 & 1710 & 9.53 & 672 & 74 & 746 & 9.92 \\
\hline
\end{tabular}

Brucellosis is a global zoonotic disease, associated with significant morbidity that can lead to increase rate of spontaneous abortion and infertility in livestock and widely distributed throughout the developing world, including Bangladesh, considered to be a serious problem in atleast 86 countries (Hamdy and Amin, 2002; Samad, 2008). The prevalence of caprine and ovine brucellosis in 13 upazillas of Mymensingh district was estimated based on RBT and iELISA. About 1710 and 746 goat and sheep samples were collected respectively based on questionnaire among the flock with any history of abortion and stillbirth, retained placenta and poor conception rate (Figure 1,2,3). Overall prevalence observed by RBT in goat and sheep was 9.53\% and 9.92\% among which ranged 0\% - 13\% Ishwarganj and Mymensingh sadar upazilla and 0\% - 13.04\% Tarakanda, Gaffargoan and Haluaghat respectively. So, 9.53\% goat and 9.92\% sheep could be infected with brucellosis which may play a great role in intra flock or other means of transmission among them or between man and animals. The highest prevalence in goat was recorded in Mymensingh sadar followed by Dhobaura upazilla as well as in sheep was in Haluaghat followed by Mymensingh sadar were 13\%, 12.9\%, 13.04\% and 12.5\% respectively.

Table 2. Age and sex-wise distribution of prevalence of caprine and ovine brucellosis

\begin{tabular}{|c|c|c|c|c|c|c|c|c|c|c|c|c|}
\hline \multirow{4}{*}{$\begin{array}{l}\text { Age } \\
\text { Distribution }\end{array}$} & \multicolumn{4}{|c|}{ Age-wise total } & \multicolumn{8}{|c|}{ Sex } \\
\hline & & & & & \multicolumn{4}{|c|}{ Male } & \multicolumn{4}{|c|}{ Female } \\
\hline & \multicolumn{2}{|c|}{ Positive } & \multicolumn{2}{|c|}{ Prevalence (\%) } & \multicolumn{2}{|c|}{ Positive } & \multicolumn{2}{|c|}{$\begin{array}{c}\text { Prevalence } \\
\text { (\%) }\end{array}$} & \multicolumn{2}{|c|}{ Positive } & \multicolumn{2}{|c|}{$\begin{array}{c}\text { Prevalence } \\
\text { (\%) }\end{array}$} \\
\hline & Goat & Sheep & Goat & Sheep & Goat & Sheep & Goat & Sheep & Goat & Sheep & Goat & Sheep \\
\hline$<6$ mon* & 14 & 6 & 8.6 & 8.1 & 3 & 1 & 1.8 & 1.4 & 11 & 5 & 6.7 & 7 \\
\hline$>6$ mon - 1yr* & 21 & 9 & 13 & 12.2 & 5 & 2 & 3.06 & 2.7 & 16 & 7 & 9.8 & 10 \\
\hline$>1-2 y r$ & 38 & 17 & 23.3 & 23 & 9 & 7 & 5.5 & 9.5 & 29 & 10 & 18 & 13.5 \\
\hline$>2-5 y r$ & 90 & 42 & 55.2 & 57 & 23 & 13 & 14.1 & 18 & 67 & 29 & 41.1 & 39.2 \\
\hline Grand total & 163 & 74 & & & 40 & 23 & 24.5 & 31.08 & 123 & 51 & 75.5 & 68.91 \\
\hline
\end{tabular}

*mon= months, yr= year(s)

The age wise distribution estimated prevalence in goat and sheep was higher in above 2 to 5 years old group than the younger and 55.2\% and 57\% respectively. According to sex wise distribution, prevalence was estimated 
higher in female (75.5\% and 68.91\%) than the male (24.5\% and 31.08\%) in goat and sheep respectively. Female in above 2 to 5 years group animals were estimated higher prevalence (41.1\% and 39.2\%) than male above 2 to 5 years group (14.1\% and 18\%). In both cases, female were found to be more susceptible than male. So, female might have act as reservoir for brucellosis. The total RBT positive samples were performed indirect enzyme linked immunosorbent assay (iELISA) which supported 33.70\% (31/92) of RBT. The prevalence and severity of the infection may vary with the breed, geographic location, type of diagnostic test, husbandry and environmental factors (Amin et al., 2005). Serological test might be a means for identification of brucellosis across the country and measures could have taken to initiate and establish a program for controlling and prevention through test and slaughter, culling of infected animal from flock and vaccination.

\section{REFERENCES}

1. Al-Majali AM (2005). Seroepidemiology of caprine brucellosis in Jordan. Small Ruminant Research 58: 13-18.

2. Al-Majali AM, Majok A, Amarin N and Al-Rawashdeh O (2007). Prevalence of, and risk factors for, brucellosis in Awassi sheep in Southern Jordan. Small Ruminant Research 73: 300-303.

3. Amin KMR, Rahman MB, Rahman MS, Han JC, Park JH and Chae JS (2005). Prevalence of Brucella antibodies in sera of cows in Bangladesh. Journal of Veterinary Science 6: 223-226.

4. Angara TEA and Ali AA (2014). Socioeconomic aspects of brucellosis in Kuku Dairy Scheme, Khartoum State, Sudan. Indian Journal of Applied Research 4: 685-687.

5. Banglapedia (2016). en.banglapedia.org/index.php?title=Goat

6. Bangladesh Economic Review (2011). http://www.mof.gov.bd/en/budget/12_13/ber/en/chapter-7_en.pdf.

7. Cutler S, Whatmore A and Commander N (2005). Brucellosis-new aspects of an old disease. Journal of Applied Microbiology 98: 1270-1281.

8. Hamdy MER and Amin AS (2002). Detection of Brucella species in the milk of infected cattle, sheep, goats and camels by PCR. Veterinary Journal 163: 299-305.

9. Jacques I, Olivier-Bernardin V and Dubray G (1998). Efficacy of ELISA compared to conventional tests (RBPT and CFT) for the diagnosis of Brucella melitensis infection in sheep. Veterinary Microbiology 64: 61-73.

10. Kabagambe EK, Elzer PH, Geaghan JP, Opuda-Asibo J, Scholl DT and Miller JE (2001). Risk factors for Brucella seropositivity in goat herds in eastern and western Uganda. Preventive Veterinary Medicine 52: 91-108.

11. Kadohira M, McDermott JJ, Shoukri MM and Kyule MN (1997). Variations in the prevalence of antibody to Brucella infection in cattle by farm, area and district in Kenya. Epidemiology and Infection 118: 35-41.

12. McDermott J, Grace D and Zinsstag J (2013). Economics of brucellosis impact and control in low-income countries. Revue Scientifique et Technique 32: 249-261.

13. Nicolino LR and Haddad JPR (2010). Brucellosis - risk factors and prevalence: A review. The Open Veterinary Science Journal 4: 72-84.

14. Olsen SC and Palmer MV (2014). Advancement of knowledge of Brucella over the past 50 years, Veterinary Pathology 51: 1076-1089.

15. Omer MK, Skjerve E, Holstad G, Woldehiwet Z and Macmillan AP (2000). Prevalence of antibodies to Brucella spp. in cattle, sheep, goats, horses and camels in the State of Eritrea; influence of husbandry systems. Epidemiology and Infection 125: 447- 453.

16. Poester FP, Samartino LE and Santos RL (2013). Pathogenesis and pathobiology of brucellosis in livestock. Revue Scientifique et Technique 32: 105-115.

17. Rahman MS, Kabir SML and Rahman MS (2015). Seroprevalence of canine brucellosis in Dhaka city corporation area, Bangladesh. Asian Journal of Medical and Biological Research 1: 17-21.

18. Rahman MS, Faruk MO, Her M, Kim JY, Kang SI and Jung SC (2011). Prevalence of brucellosis in ruminants in Bangladesh. Veterinární Medicína 56: 379-385.

19. Rahman MS (2005). Serological and bacteriological diagnosis of Brucella abortus biotype 1 infection in SpragueDawley rats. Indian Journal of Animal Sciences 75: 610-616.

20. Samad MA (2008). Animal husbandry and Veterinary Science. Volume 2. LEP No. 11, BAU campus, Mymensingh. pp.1219-1225.

21. CFSPH (The center for food security and public health) (2009). Iowa state university. http://www.cfsph.iastate.edu/Factsheets/pdfs/brucellosis_melitensis.pdf.

22. WHO (2006). Brucellosis in human and animals. Joint report of WHO, FAO and OIE. 